\title{
Hamlet and Oblomov: A Comparative Study
}

\author{
Javed Akhter, Shumaila Abdullah, Khair Muhammad \\ Department of English Literature and Linguistics, University of Balochistan, Quetta, Pakistan
}

Email address:

sangatjavedakhtar@gmail.com (J.Akhter),Shumaila_abdullah914@yahoo.com (A. Shumaila), Khairefroze@gmail.com (K. Muhammad)

\section{To cite this article:}

Javed Akhter, Shumaila Abdullah, Khair Muhammad. Hamlet and Oblomov: A Comparative Study. International Journal of Literature and Arts. Vol. 3, No. 5, 2015, pp. 108-119. doi: 10.11648/j.ijla.20150305.17

\begin{abstract}
The aim of this research paper is to explore by comparing and contrasting between the two literary characters Hamlet and Oblomov how they are in their essence indecisive that are exploited by William Shakespeare and Ivan Goncharov in different historical ages to project different visions of the human situation. Every author is influenced by his age to certain degrees and if the art of characterization of William Shakespeare is set against that of Ivan Goncharov, it is because of the difference of ideological perspectives. William Shakespeare's character Hamlet comes from the Renaissance England and Ivan Goncharov's character Oblomov comes from the nineteenth century Russia. The former is in certain ways different from the latter despite the fact that those traits of the both characters are the same as indecision and procrastination. The comparison and contrast will be highlighted in this paper in terms of Marxist hermeneutics, which is scientific theory and method of analyzing the social and literary types in the context of class milieu. Applying Marxist literary hermeneutics to the art of characterization of both the authors, the present study tries to introduce new portrait and re-evaluation of the personages of the two literary types in an innovative perspective.
\end{abstract}

Keywords: William Shakespeare's Hamlet, Ivan Goncharov’s Oblomov, Sluggishness, Procrastination, Indecision, Hamletism and Oblomovism

\section{Introduction}

Typicality or characterization is one of the most important aesthetic rules of artistic production of literature. The art of characterization or typicality not only makes the author famous but also makes the literary types memorable and universal. Indeed the literary types or characters are the reflection of men in the historical ethos of the social formation. The most memorable typical characters in literature possess verisimilitude, breadth and precise detail that make of the essential features or processes discernable within socio-political conditions of the social formation in which they are produced. Fredrick Engels says of typicality in literature as follows:

"Realism to my mind implies, besides truth of detail, the truthful reproduction of typical characters under typical circumstances" (Marx, Karl and F. Engels, 1965, pp. 401). This well-known statement of Fredrick Engels points to the significance of the typical in literature.

William Shakespeare possesses a mastery of the art of typicality and characterization in his plays, providing an insight into psychology of human beings that he produced variety of memorable and universal literary types in his plays, which transcend the limits of time and space. Therefore, his plays help to understand human psychology. Hamlet is one of the most debatable and controversial characters of William Shakespeare. The story of "The Tragedy of Hamlet, Prince of Denmark" concerns a young man, Hamlet, son of the late King of Demark who communes with a ghost of his dead father, who talks only to him and instructs him to commit a revenge of his murder. The story ends with the tragedy of mass murder. The prince Hamlet grows up, confident in his privileged status in the royal court of Denmark. Therefore, he is well aware of his role in the given social formation. The traditional idea of ancestral revenge, an idea existing in the social formation before social classes became one of the pillars of the feudal world ideology, which is minimized and almost utterly discarded in the tragedy. Hamlet is 'not entirely free from the idea of revenge, but he has lost the urgent impulse for it because of indolence, indecision and procrastination. The play reflects the transitory historical period from feudalism to capitalism in which indolence, procrastination and irresolution prevailed in the social formation of England. Vanessa Pupavac states in her paper entitled "Hamlet's Crisis of Meaning, Mental Wellbeing and Meaninglessness in the War on Terror" as follows: 
"Shakespeare's drama takes us to the historic juncture between the old feudal order and rise of the modern, and their conflicting values. Drama is quintessentially about crisis created by an uncle's murder of his brother and usurpation of the throne. Hamlet's psychological crisis is precipitated by his inability to act against his uncle King Claudius and reconcile contradictory normative imperatives." (Pupavac, Vanessa, 2008, p.15).

However, "The Tragedy of Hamlet, Prince of Denmark" is one of the great tragedies William Shakespeare and masterpieces of world literature, which has always been a focal point of research and critical debate. From the day of William Shakespeare until the present time at least ever literary theory has been applied to analysis psychologically complex and tragically flawed character of Hamlet. This paper tends to compare Hamlet with Oblomov. Oblomov is the hero of Ivan Goncharov's novel "Oblomov". Ivan Goncharov (1812-1891) is one of the great realist Russian novelists of the nineteenth century. His masterpiece "Oblomov" (1859) is one of the greatest Russian novels, which constitutes a study of a perfectly new type in Russian literature, of a land-owning and serf-owning feudal lord who, though plunged in a slough of apathy from which nothing can arouse him, is yet a man of fine and noble instincts. What he utterly lacks and is ruined by, is his total lack of will power and resolution. Oblomov is likewise a study in the gradual collapse of illusory ideals and recognition of the real facts of the nineteenth-century Russian social formation. His figure in his dressing-gown has become a class image of slothfulness of the landed and serf-owning nobility.

In this manner, Ivan Goncharov depicted Oblomov in such a realistic manner that he has become immortal, passing into the Russian as well as other European languages. Therefore, Oblomov becomes immortal and memorable literary type in Russian Literature as Tartuffe in French literature and Pecksniff in English literature. Oblomov has not suddenly come down in Russian literature but in fact, he is developed form and culmination of the gentry hero familiar to us already from such types as Alexander Pushkin's Onegin and Mikhail Lermontov's Pechorin. He bears universal attributes, which place him alongside such universally recognizable types as Hamlet, Don Quixote and Don Juan. In this regard, Oblomov is the first example of large-scale artistic portraiture in Russian Literature. His characterization is assumed to mean not only the relationship of the characters to the land-owning and serf-owning feudal social formation of Tsarist Russia, but relating as nearly as feasible of the totality of a character's experience, from boyhood to death.

Ivan Goncharov places Oblomov in the squalid setting of his apartment in Westernized imperial capital St Petersburg, where at the opening of the novel he spends a whole day in a shlafrok dressing-gown, rejecting the overtures of the visitors from the cold outside world or quarrelling with his serf Zakhar. He possesses three hundred serfs in his county estates of Oblomovka. He is principally such kind of lethargic person who, shortly roused from his dressing-gown torpor by the attraction of the novel's heroine, Olga
Sergievna. Subsequently, he spends an enchanted summer in gentle courtship of her (part 11 and 111 of the novel), only to retreat again into his dressing-gown existence when the cold winter season approaches. However, there are the lovingly designed vistas of 'Oblomov's Dream' or the chorus-like commentaries of the novel's 'positive' hero, Schtoltz, beyond this principally static and fluidly episodic twofold portraiture, which provides perspective of time and meaning to Oblomov's characterization.

The fact is that these two literary characters (Hamlet and Oblomov) have their own social background of their epochal periods. Therefore, they have the impact of different socioeconomic conditions, infrastructural developments and ideological suprastructrural levels of the two different social formations to which they belong. In fact, these literary characters are product of the social formation of feudalism, belonging to the feudal nobility and hence indecision, procrastination and sluggishness are the characteristics of the class of land-owning and serf-owning feudal nobility, which produce such type of "European-style snobs", the "useless chaps" and "the superfluous heroes". However, these both literary characters come from the two different transition periods from feudalism to capitalism. Hamlet comes from the Renaissance period and Oblomov comes from the mid nineteenth-century. These two epochs are periods of transition from the old order of feudalism to the new order of capitalism. Therefore, the continuous process of rejection of the old values and acceptance the new ones, had not yet completed, so confusion, indolence, procrastination and indecision are prevailed all over the both periods. That is why Hamlet and Oblomov represent this socio-historical situation of class confusion, indolence, procrastination and irresolution of the land-owning and serf-owning feudal nobility.

In this research paper, the researcher has highlighted the comparative study of the memorable and universal literary characters of Hamlet and Oblomov, utilizing Marxist interpretative tools of comparative literature. Marxist approach to Hamlet and Oblomov does not need the vulgarities of crude overstatement, nor must it-----as vulgar materialist and sociologist critics often attempt far too crude short cuts from economic to literature. For this reason, the comparison between Hamlet and Oblomov is conducted in this research paper in terms of Marxist hermeneutics and in the light of the brilliant ideas of the above-mentioned Marxist literary critics. This Marxist comparative study is fundamentally not any different from the study of national literature, except its subject matter is much vaster. Instead of confining itself to the wave of single historical epoch, this paper looks beyond the specific boundary of frontier in order to discern trends and movements in the light of the socioeconomic conditions of the two different historical epochs.

\section{Literature Review}

The love and respect of William Shakespeare was a veritable cult in Karl Marx's household. Karl Marx's wife Jenny and his daughters engrossed and staged William 
Shakespeare's plays in their home. Both Karl Marx and Fredrick Engels were soaked in William Shakespeare, and the few direct comments we have on his work from them are exceedingly valuable as suggestions for a study of his art. William Shakespeare's play enriched Karl Marx's vocabulary because Karl Marx resorted extensively to the characters and language of Hamlet. He used the play's uncanny ghost and undertakers, which are lurking in "The Communist Manifest's images and visions: "spectre haunting Europe" (Marx and Engels, 1975, p. 473) and the bourgeoisie producing its own "grave-diggers" (Marx and Engels, 1975, p. 483). He also quotes Hamlet's "well grubbed old mole" to figure the subterranean processes of social transformation, which will eventually lead to capitalism's demise (Marx and Engels, 1975, p.606). Gabriel Egan's book "Shakespeare and Marx" (2004) is very important, which sheds lights on Marx's reading of William Shakespeare.

Afterwards, Many Marxists literary critics devoted their full attention to William Shakespeare. John Maynard Keynes studied William Shakespeare in his book "A Treatise on Money" (1930). Christopher Caudwell discussed Hamlet in terms of classical Marxist literary theory in his book "Illusion and Reality" (1977). Many other Marxist critics did so. Professor Smirnov interpreted William Shakespeare's in a similar manner, for example, in his analysis of the tragedy Hamlet in Classical Marxist lens in his book "Shakespeare: A Marxist Interpretation" (1936) is an example of such type of Marxist criticism. However, these critics' Marxist study of William Shakespeare is naive in many respects because they attempt far too crude short cuts from economic to literature. Moreover, many Marxist literary critics, including Karl Marx and Fredrick Engels studied Hamlet in new and innovative Marxist perspective. Anatoly Lunacharsky, A. A. Smirnov, Mikhail Lifshitz, Christopher Caudwell, Alick West, Ralph Fox, L.C Knight, Georg Lukacs, Bertolt Brecht, Raymond Williams and many others describe Hamlet's character in early classical Marxist perspective. Mikhail Lifshitz' criticised A. A. Smirnov's book "William Shakespeare: A Marxist Interpretation" for distortion of Lenin's theory of reflection in his "Literature and Marxism: A Controversy" (1938). Many Marxist critics applied Lenin's theory of reflection to interpret William Shakespeare. The best example of which is Georg Lukacs' theory of realism. He remarks on the plays of William Shakespeare as follows:

"The example of Shakespeare's great tragedies is particularly instructive, because in them the specifically dramatic character of historical charges, of dramatic historicism, is clearly manifest. As a true dramatist, Shakespeare does not try to point a detailed picture of historical and social circumstances. He characterizes the period through his actors. That is, all the qualities of a character, from the ruling passion down to the smallest 'intimate,' yet dramatic, subtlety, are coloured by the age. Nor necessarily in a broad or epic historical sense, but certainly in the historical conditioning of the collision; its essence must derive from the specific determinants of the epoch" (Lukacs, Georg, 1981, p. 137).
On the Other hand, the Marxist literary critics of present time studied Hamlet in a new Marxist perspective. The British Marxist literary theorist Catherine Belsey studied William Shakespeare in her book "Critical Practice" (1980) in an innovative Marxist perspective. In this respect, the most eminent British Marxist critic Terry Eagleton's Marxist study of William Shakespeare is also very important and worthmentioning. His Marxist analysis of Hamlet's character is very interesting and thought provoking in the section on Hamlet in his book "William Shakespeare" (1986). For him the character of Hamlet is "decentred" who does not wish to be part of the Lacanian "symbolic order", moves toward "bourgeois individuality, possesses no "essence of being" whatsoever, no inner sanctum to be safeguarded: he is pure deferral and diffusion, a hollow void which offers nothing determinate to be known (Eagleton, Terry, 1986, pp. 71- 75). The most updated American Marxist critic Fredric Jameson also analysed Hamlet in his paper entitled "Marx' Purloined Letter" (1995), reviewing Jacques Derrida's book "Spectres of Marx" in innovative and brilliant Marxist perspective. Richard Halpern's intelligent critical response to "Derrida's Reading of Hamlet and Marx" (2001) in a Marxist perspective, is also an illuminating essay in Jean Howard and Scott Cutler Shershow's edited collection entitled "Marxist Shakespeare" (2001). Peter Stall brass's essay on Marx's haunting by Shakespeare in the same collection is also worth mentioning.

Ivan Goncharov's novel "Oblomov" and its central characters such as Oblomov and Andrey Schtoltz were imbued with controversial opinions by the Russian critics of the 1860s immediately following the publication of the novel. Nikolai Aleksandrovich Dobrolyubov wrote the most celebrated essay entitled "What is Oblomovism?" This critical review appeared in the journal "The contemporary" in May 1859 in which he analysed the social aspect of the character of Oblomov, applying the theory of sociological criticism of Belinsky as a tool. In contrast to Oblomov, he regarded the character of Andrey Schtoltz as an "antidote" to the character of Oblomov because of his mobility, progress, new ideas and revolutionary sprite. For this reason, this essay generated a great controversy between the radical revolutionary democrats and the liberals of the sixties, confronting with each other in Russia in those days. Alexander Herzen, one of the liberals, answered Nikolai Aleksandrovich Dobrolyubov with an essay entitled "Very Dangerous" in which he showed his disagreement with Nikolai Aleksandrovich Dobrolyubov's standpoint. However, this controversy set a new fashion in literary criticism to compare the two characters of the novel from different opinions. In Galya Diment's view, the character of Andrey Schtoltz is a "prototype" for the future that is "too schematic" (Diment, Galya, 1998, p. 30). D. Senese presents a re-evaluation of Nikolai Aleksandrovich Dobrolyubov's critical review of the novel, considering the character of Andrey Schtoltz as a "plot device and foil" (Senese, D., 2003, pp. 88).

While Nikolai Dobrolyubov's criticism devalues the importance of Andrey in the narrative, it does not dismiss 
entirely the notion of a character such as Andrey existing in Russia, and the critic invokes the 'author's acknowledgement" that Andreys would arrive "with Russian names" in the future. Nikolai Dobrolyubov, therefore, takes issue not with the substance of the character (as subsequent critics would), but rather with the timeframe (Seeley, 2003, p. 336). "While many critics have bristled at the supposition that Goncharov intended for Andrey, the German (or halfGerman) to save Russia from Oblomovism" (Diment, Galya, 1998, p. 30). Indeed, if Dobrolyubov were to take this character as possible in the present tense his argument would collapse, because he reads the novel as a social document, similar to Belinsky's literary criticism (Stacy, 1985, p. 101). This viewpoint has led Kuhun to argue that Dobrolyubov's essay had many goals, such as an attack upon Herzen's interpretation of "superfluous hero" but that "none of (them) were strictly literary" (Kuhn, 1971, p. 97). If Dobrolyubov had admitted the possibility of Andrey's existence in Russia, there would be no foundations to portray Oblomovism as a general social malady pervasive across Russia and as an inevitable result of serfdom. Dobrolyubov's criticism of Andrey as an unrealistic character was therefore grounded in the critic's goal to use literary works of art as a springboard to broader social critique (Setchkarev, 1967, pp. 1799-1800).

For this reason, McLean treats Andrey Schtoltz character as a "theoretical abstraction" (McLean, 1998, p. 50). M. Shishkin also regards the character of Andrey Schtoltz as an antipode of the character of Oblomov (Shishkin, M., 2008, pp. 545-552). A. Muza regards the character of Andrey Schtoltz as a "topos of the German element in Russia" (Muza, A., 2000, p. 186). All approaches of the contemporary critics of Ivan Goncharov to judge the character of Oblomov made absolute the social aspect of the character and ignored all the rest. Such type of critical interpretations is limited to diametric oppositions between the two characters (Setchkarev, 1967, pp. 1799-1805; Ehre, 1973, p. 197; Peace, 1991, p. 13). F. Seeley's paper "The Heyday of the 'Superfluous Man' in Russia," Franklin Reeve's paper “Oblomovism Revisited," Kathleen Cameron Wiggins' Ph.D. dissertation entitled "the Drama in Disguise: Dramatic Modes of Narration and Textual Structure in MidNineteen-Century Russian Novel" and Leon Stallman's essay "Oblomovka Revisited," are exhaustive and thoughtprovoking research works on the Oblomov's phenomenon.

Contrary to the diametric comparative tradition, Joshua S. Walker presents a comparative and contrastive study between the characters of Oblomov and Andrey Schtoltz in his article entitled "Neither Burgher nor Barin: An Imagological and Intercultural Reading of Andrey Schtoltz in Ivan Goncharove's Oblomov (1859)." He challenges the previous theories that give privilege the character of Andrey Schtoltz over the character of Oblomov, proving him as antidote and antipode of the character of Oblomov. Joshua S. Walker states that Andrey Schtoltz is "as more than either a weak point in the novel or as plot device and simple foil to Oblomov" (Walker, Joshua S., 2013, p. 5). In doing so, he utilizes the Imagological methodology, a new school of criticism that took shape in France in the 1950s and gained a scholarly following in the following decades in Germany (Leerssen, 2007, pp. 17-32).

These books and research papers are sound interesting, most informative and thought provoking on both of the characters: Hamlet and Oblomov in many respects, but no one has yet attempted to compare Hamlet with Oblomov. However, as this literature survey proves that both literary characters are indecisive, indolent and irresolute in their life, therefore, they may be compared on these grounds. For this reason, Abu Saleh Md. Rafi in his research paper, "The Comparative Nature in Comparative Literature: A Case-study of Some Major Bengali Literary Works in Conjunction of Other National Literatures", suggests that "the Russian novel Oblomov may be compared to Hamlet because each work is a character study of indecision and procrastination" (Rafi, Abu Saleh Md., 2012, p. 2 ). This suggestive clue has inspired me to attempt a comparative study of the literary characters of Hamlet and Oblomov. So on this ground, a comparison is conducted between the two literary characters: Hamlet and Oblomov, applying and utilizing Marxist literary theory and method. Instead of comparing the two literary characters setting one against another, it provides a method of broadening one's perspective in the approach to the single works of literature. Therefore, Marxist literary theory and method of comparison may be used in literary study to indicate 'affinity', 'tradition' and 'influence'. With a view of designating Marxist literary theory and method, the current research paper studies the two literary characters in conjunction of the two different historical epochs and social formations to which these two literary types belong. For this reason, the comparison of Hamlet with Oblomov is conducted in this research paper in terms of Marxist hermeneutics and in the light of the brilliant ideas of the above-mentioned Marxist literary critics.

\section{Comparison Between Hamlet and Oblomov}

Hamlet nevertheless finds himself increasingly affected by the circumstances, in which he encounters the crisis of state, and though he gradually experiences the sudden death of his father and incestuous marriage of his mother with his uncle King Claudius. Marcellus's phrase in the opening act reveals the dark suspicions of rottenness in the state of Denmark, "Something is rotten in the state of Denmark" (Shakespeare, William, 2005, Act 1, Scene IV, 67). The reason of the rottenness of the feudal State of Denmark is not moral but a result of declining the old feudalism and emergence of capitalism. This transitory historical epoch begins to break up the old feudal institutions and establish the capitalist ones instead. Hamlet was written in this age of transition that called the Renaissance period, which was a transitory period from feudalism to capitalism in Europe. The age of William Shakespeare was the era of the Renaissance in England. It is the era of the radical upheaval in socio-economic ethos of 
social formation of Elizabethan age, when the decline of the old feudal order with its modes of production, which was now being replaced by capitalist relations characteristic of the epoch of this primary accumulation. The new economic forces gave rise to a New England. The first upheaval in old feudal system affected the old feudal agricultural relations.

In this sense, Hamlet is product of the Renaissance age. He is essentially a man of the new age as a humanist of Renaissance age. In Renaissance era, a rising capitalist economy made serfdom disappeared throughout England in the fifteenth century because it was more profitable to hire labour. The wool industry, export markets, and sheep-raising flourished tremendously everywhere in England, which, created a heightened demand for pastureland. As a result, the enclosure system aroused. The rich feudal lords made forcible seizure of the commons from the peasants possible in the close of the fifteenth and throughout the sixteenth century. Moreover, with the growth of the wool industry much cultivated land belonging to the landlords was transformed into sheep-walks. The great mass of the peasantry found itself deprived of any land to cultivate. Therefore, a great supply of free agricultural labour was available, to work for a pittance to stave off hunger. This was a fundamental prerequisite for the development of capitalist industry. The sale of confiscated church land by the state also satiated land hunger after the advent of the Reformation, about 1535. The bourgeoisie purchased Most of the land from the old feudal lords. Thus, the old landowners and the new bourgeoisie were united, since the former began to be bourgoisified nobility, applying new capitalist methods to agriculture. However, it carried over its old ideology into the new agricultural relations.

This new situation formed the so-called gentry, composed principally of the middle and petty landed and serf-owning nobility, which, by fusing with the old landed nobility, replenished its ranks, which marked the beginning of that squirarchy which ruled England from the time of Queen Elizabeth to the middle of the nineteenth century. The new class of wealthy peasant farmers, the so-called yeomanry that was the backbone of old England, degenerated during the sixteenth century. This new landowners drawn from the bourgeoisie and the nobility dislodged it. Therefore, it was forced to accept the status of tenants. The new joint-stock companies (including the paying troupes) were protocapitalist and operated outside the regulatory systems of the guild structure. They depended on monopolies granted by the monarch in Britain. Catherine Belsey inadvertently gets closer to the nub of the matter when she observes, ".the selling monopoly was one of the means by which the Tudors and Stuarts sought to evade parliamentary control," so that rather than a simple struggle between the old feudal ways embodied in a modified monarchy and the demands of the rising urban bourgeoisie (Belsey, Catherine, 1985, p. 93).

The beginnings of this gigantic moral and social cataclysm existed in William Shakespeare's time and he reflected it with exceptional clarity and depth. The old social and moral values were collapsing and no new ones had yet been substituted. The new humanist bourgeoisie or bourgoisified nobility formulated the Puritan morality with all its class limitations. Hamlet therefore wished to produce a new morality based upon the great ideas and problems advanced by the humanist bourgeoisie or bourgoisified nobility of the Renaissance period, which, in turn, had been derived from all the social classes except the ruling landed and serf-owning feudal class. In fact, the new bourgeoisie was yet in its infancy. Hamlet is filled with "worldly sorrow." He sees the break, which had already started in the old world of feudal morality. He wants to exert all his efforts to destroy the old feudal ideology. In his monologue "to be or not to be", he reaches the highest point of scepticism possible at that time. Hamlet's reasoning that "your worm is your only real emperor for diet," that "your fat icing and your lean beggar is but variable service, two dishes, but to one table" (Shakespeare, William, 2005, Act IV, Scene, 111), destroys the idea of feudal monarchy in particular, and the entire feudal dogma of class hierarchy in general. Therefore, Hamlet turns largely sceptical about what he sees as degrading customs and general opinions of the given social formation. " And indeed Hamlet dreams of a world which has been somehow made straight, a world of honest people, honest relationships, but he does not believe that such world will ever in fact become reality" (Lunacharsky, Anatoly, p. 237). Hamlet says to Rosencrantz and Guildenstern "Then are our beggars bodies, and our monarchs and outstretched heroes the beggars' shadows," (Shakespeare, William, 2005, Act II, Scene 2). Moreover, Hamlet says to the gravedigger, "The toe of the peasant comes so near the heel of the courtier, he galls his kibe," (Shakespeare, William, 2005, Act $\mathrm{V}$, Scene 1), which hints at agrarian revolt. This point proves that Hamlet is anti-feudal, humanist democratic of the Renaissance age.

Therefore, Hamlet does not mourn the old dying world of feudalism but he shudders at the sight because he does not see a new world that will satisfy him. Caught between the corruption of the court, the vulgarity of the growing bourgeoisie, and the masses in which he has no belief, there is only one outlet for him: the half-pretended madness and apathetic action by which he accidentally brings about his futile revenge before he himself perishes. The situation was truly dialectical: the aristocracy, not the bourgeoisie or bourgoisified nobility produced the conditions for primary wealth accumulation that made Britain the first capitalist economy. However, the portrayal of Hamlet is bound up with dying the old order of feudalism and the new order of capitalism, which is yet seeking to be born. In this way, he comes in conflict with the socio-economic conditions of declining feudalism; when this situation arises, inner changes occur in Hamlet's personality. In this perspective, the flawed figure of Hamlet represents transitory phase of the Elizabethan social formation of England. As Terry Eagleton states, "Hamlet is a radically transitional figure, striking out between a traditional social order to which he is marginal, and a future epoch of achieved bourgeois individualism which will surpass it. But because of this we can glimpse in 
him a negative critique of the forms of subjectivity typical of both of these regimes" (Eagleton, Terry, 1987, p.74). Terry Eagleton further says, "Hamlet moves toward the realm of bourgeois individuality" (Eagleton, Terry, 1986, p. 74). In his view the character of Hamlet is "opacity" that means the "enigmatic being....legendary in world literature" (Eagleton, Terry, 1986, p. 74).

In Louis Althusser's "Ideology and Ideological State Apparatuses", the state possesses a central role in construction of the individual as subject. Ideology and ideological state apparatuses constitute individual's identities and determine his role in the given social formation. Similarly, Hamlet's interest in actors and acting has in common in Louis Althusser's concern for the means by which individual's sense of who he is? is a form within ideology and ideological state apparatuses that is constituted within the social norms and for apparently authentic selfhood being a role that one has been assigned by the social formation. Rejecting Gertrude's "Why seems it (grief at death) so particular with thee?" (Shakespeare, William, 2005, Act 1, Scene 11, 76-85), Hamlet insists:

"Seems, madam? Nay, it is. I know not 'seems'.

'Ts not alone my inky cloak, good-mother,

Nor customary suits of solemn black,

Nor windy suspiration of forced breath,

No, nor the fruitful river in the eye,

Nor the dejected haviour of the visage,

Together with all forms, moods, shows of grief

That can denote me truly. These indeed 'seem',

For they are actions that a man might play;

But I have that within which passeth show,

These but the trappings and the suits of woe" (Shakespeare, William, 2005, Act 1, Scene 11, 76-85).

Therefore, Hamlet is obsessed with not being interepellated by Danish ideology and ideological state apparatuses, with not performing a role assigned to him, with remaining "not a pipe for Fortune's finger. To sound what stop she please" (Shakespeare, William, 2005, Act 111, Scene 11, 68-69), "do you think I am easier to be played on than a pipe?" (Shakespeare, William, 2005, Act 111, Scene $11,357-358)$. In this way, Hamlet is much impressed with the effect of performance upon the performer:

"Is it not monstrous that this player here,

But in a fiction, in a dream of passion,

Could force his soul so to his whole conceit

That from her working all his visage waned,

Tears in his eyes, distraction in's aspect,

A broken voice and his whole function suiting

With forms to his concert?" (Shakespeare, William, 2005, Act 11, Scene 11, 553-559).

Louis Althusser conceded that it was in ideology and ideological state apparatuses or socio-political institutions such as the school, the family and the media, that the domination of a ruling class was first installed 'in words' (Althusser, Louis, 1971, pp.127-186). Ideology hails or interpellates individuals as subjects, which has alwaysalready interepellated individuals as subjects. Therefore,
Louis Althusser's performative model of ideology is crudely expressed in such line of William Shakespeare: "you are what you do", inasmuch as he thought of the relationship between social forces and the individuals as a kind of dramatic casting of role that makes one feel individually appreciated (by personal 'hailing') when in truth any person could take one's place. For Louis Althusser ideology and ideological state apparatuses construct the individual as subject. In this way, Ideology constitutes individual identities and determines his social role in the given social formation. As a result, Individual's sense who he is? is a form within ideological state apparatuses and for apparently authentic selfhood being a role that one has been assigned by the given social formation.

However, the Danish ideology and ideological state apparatuses such as family, royal court, education and the ghost of Hamlet's dead father constitute Hamlet as subject, to realise him that he is sole and real heir of the throne of Denmark, assigning his role to instruct him to take his revenge from the King Claudius and take the throne of Denmark. The other Ideological state apparatuses also make Hamlet believe that he is sole and real heir of the state of Denmark and assigned him the role to take revenge of his father from his uncle King Claudius and gain the kingship of Denmark. In this manner, Hamlet becomes shaped and circumscribed as subject by social structures, values, assumptions and ideologies. His upbringings in the royal court His royal upbringing and higher education make him believe that he is an extraordinary person in Demark. Therefore, he privileges and protects his unique sense of self and regards this feeling as a source of value. When he thinking, "The time is out of joint: O cursed spite,

That ever I was born to set it right!" (Shakespeare, William, 2005, Act 1, Scene V, 197).

In this sense, Hamlet shoulders the burden of his responsibilities and duties assigned by the ideological state apparatuses. By adhering to his father's dictum and 'setting things right', Hamlet will not be acting on his own terms in his own way. Instead, Hamlet cannot find a proper way to act and exist. However, Hamlet's short-lived enthusiasm reduces to prudentially relaxing in indolence and procrastination. His father's ghost informed him that he was murdered by Claudius. In this way, the duty and responsibility of revenge falls upon Hamlet but he feels himself ill-situated for it. He feels his inadequacy for the task imposed upon him. Thus, Hamlet cries out against his fate that requires him to act: When Hamlet finds his own death warrant in the purloined letter, (Shakespeare, William, 2005, Act 1, Scene v, 197), Hamlet seems to be confirmed in that view and leaving it to chance because he realizes the power of destiny:

".and that should learn us

There's a divinity that shapes our ends,

Rough-hew them how we will" (Shakespeare, William, 2005, Act V, Scene 11, 10).

Therefore, Hamlet's all utterances show ideology of time because ideology is present in every word he utters in his speeches. As Catherine Belsey said that ideology is engraved 
in each and every utterance and use of language but there are some other signifying systems of the social formation also where its presence can be traced easily: common sense, everyday behaviours mores and folkways, myths, social gestures and routine truisms are relevant signs in this regard (Belsey, Catherine, 1980, pp.56-85). However, Hamlet, fails to take revenge and regain the kingship of Denmark because of indolence, indecision and procrastination. Hamlet never decides to revenge his father from King Claudius. He accepts his fate without trying to determine circumstances beyond his prowess. When Horatio points out that his time is short, Hamlet says that, "It will be short. The interim is mine. And a man's life no more than to say one" (Shakespeare, William, 2005, Act V, Scene.11, 73-74). Hamlet recognizes his shortcomings and accepts the consequences of his actions. Finally, he does nothing. However, judging from his soliloquies, which offer more and more depth into his character as the play progresses; the struggle he faces is, causing him a considerable amount of personal strife. In this way, Hamlet fails to revenge his father from the guilty King Claudius when he finds him in a pose of prayer kneeling alone for prayer. "Now might I do it pat, now a is a-praying.

And now I'll d't. (Draws his sword)

And so a goes to heaven

No.

Up, sword, and know thou a more horrid hent:

When he is drunk asleep, or in his rage,

Or in th'incestuous pleasure of his bed,

At game a-swearing, or about some act

That has no relish of salvation in't,

Then trip him that his heels may kick at heaven

And that his soul may be as damn'd and black

As hell, whereto it goes" (Shakespeare, William, 2005, Act

3, Scene 3, 73-95).

Hamlet's last soliloquy expresses his frustration and cynicism as Fortinbras marches off to conqueror

"a little patch of ground

That hath in it no profit but the name" (Shakespeare, William, 2005, Act IV, Scene IV, 18-19): Hamlet complains his fate that, "How all occasions do inform against me...." (Shakespeare, William, 2005, Act IV, Scene IV, 32). What happens to Hamlet on the way to England is like the last beam falling. This change begins with insomnia and the same old inner conflict in his personality. He finds himself in a perpetual state of restlessness: "Sir, in my heart there was a kind of fighting. That would not let me sleep" (Shakespeare, William, 2005, Act Scene 11, 4-5). However, Hamlet is indecisive person, as he seems, but we find that he is given up on life or perhaps, as he claims later on in the play, he is only pretending he is given up so his actions will be less suspicious. This is even more impressive when taken in light of Terry Eagleton's point in a much-quoted passage, in his short book "William Shakespeare" (1986) suggests that "Hamlet has no 'essence' of being whatsoever, no inner sanctum to be safeguarded: he is pure deferral and diffusion, a hollow void which offers nothing determinate to be known.” (Eagleton, Terry, 1986, p. 72).
In fact, Hamlet's postponement of the killing of Claudius is his reluctance to murder Claudius while praying that his soul should enter heaven. However, it is not so much his confusion and hesitation, as the tone that Hamlet adopts when he speaks of his revenge that proves him lacking in will-power. He is horrified by the crime, by his mother's inconstancy in marrying the usurper, "ere those shoes were old," and by the rampant hypocrisy and debauchery of the entire court, even of his beloved Ophelia, a debauchery and hypocrisy, which he attributes to the world at large. It never occurs to him to take revenge as an act of personal justice. Finally, Hamlet contemplates the meaning of suicide because of his father's unexpected death and his mother's indecent hasty marriages, which have led him to think about 'selfslaughter' (Shakespeare, William, 2005, Act I. Scene 11.132). Then he teasingly speaks of walking out of the air and into (his) grave' (Shakespeare, William, 2005, Act II. Scene ii.204) with Polonius. He is astonished by the men in Fortinbras' army, who can 'Go to their graves like beds' (Shakespeare, William, 2005, Act IV. Scene iv.61) for a plot of land that would not be big enough to bury them all in. In his soliloquy beginning 'To be or not to be', in which he meditates on the desirability and the fear of death, Hamlet suggests that reflection is the adversary of suicide: "To be, or not to be - that is the question" (Shakespeare, William, 2005, Act III. Scene 1.55).

Moreover, his following soliloquy reveals his disappointment and hopelessness, "How weary, stale, flat and uncomfortable

Seems to me all the uses of this world" (Shakespeare, William, 2005, Act 1, Scene 11, 133-134). Later in this soliloquy, his thinking abruptly switches from self-torment to putting on a play. Hamlet's mind gets the better of him again.

"To be or not to be- that is the question:

Whether 'tis nobler in the mind to suffer

The slings and arrows of outrageous fortune,

Or to take arms against a sea of troubles" (Shakespeare, William, 2005, Act 111, Scene 1, 56).

In fact, Hamlet is largely sceptical about what he sees as degrading customs and general opinions of the given social formation. He finds it difficult to avenge his father's murder. Yet he still feels an obligation to fulfil these expectations. Something of this idea emerges when Hamlet gives advice to his mother in the closet scene. He tells her, "Assume a virtue if you have it not. That monster Custom, who all sense doth eat. Of habits devil, is angel yet in this, That to the use of actions fair and good He likewise gives a frock or livery That aptly is put on" (Shakespeare, William, 2005, Act III. Scene 1V.158-63). Therefore, Hamlet's response towards his mother's over hasty marriage with King Claudius is made known as early as the second scene. Hamlet speaks, "A little more than kin and less than kind" (Shakespeare, William, 2005, Act 1, Scene 11, 66). This indicates that Hamlet already suspects something afoul is afoot. Later in the same scene, during his first soliloquy, he describes his disgust with his mother's over hasty marriage, but tells himself he must keep quiet: "But break, my heart, for I must hold my 
tongue". In fact, Hamlet is not a natural fighter but he is brooding thinker, and bookish dreamer. However, Hamlet becomes entrapped in indecision and procrastination. He bears the latent passion of a hesitating breeze. He breathes with hesitation, irresolution and delay. Hamlet's purpose exists in a perpetual state of twilight of confusion and indecision. Repeatedly, his compulsive tendency to analyse and question distracts him away from revenge in every situation he faces. He is tragically doomed to failure to revenge. In this manner, he turned epitomized in conflict of wills as Christopher Caudwell remarks:

"In Hamlet the problem of conflict of unmeasured wills is posed in yet another form - here a man's will is divided against itself, and therefore even though nothing 'external' can oppose or reflect it, it can yet struggle with itself and be wrecked. This 'doubleness' of a single will is aptly symbolized by the poisoned swords and goblet in which one aim is as it were two-faced, and secures opposite ends" (Caudwell, Christopher, 1977, pp. 87-88).

In the 19th century, Ivan Goncharov produced a literary type in the personage of Oblomov, an indecisive and lethargic person who has become an immortal and memorable type in Russian Literature as Tartuffe in French literature and Pecksniff in English literature. However, Oblomov is an embodiment of laziness, inertia, procrastination, and indecision of the land-owning and serfowning feudal nobility of the nineteenth-century Tsarist Russia. Ivan Goncharov gave a comprehensive expression of indecision, procrastination and sluggishness of the landowning serf-owning feudal class of Tsarist Russia. However, the feudal Tsarist Russian ideology and ideological state apparatuses construct Oblomov as subject and make him realise to protect the old order of serfdom as his estates are deteriorating rapidly day by day. However, he does nothing to save his estates because of inertia, procrastination and indecision. He declares to his servant his worry about the worsening condition of his estates, but does nothing about it. Although, he produces no tangible results, he does spend his time planning reforms "along western lines" (Peace, 1991, p. 13). The family and estate's name itself tells the reader about the condition that the residence was in the Russian word Oblomov means a broken-offs piece. When Oblomov had received an exceedingly unpleasant letter from the starosta (overseer or steward) of his country estate, he became disturbed. The letter described bad harvests, arrears of debt, and diminished incomes. The bulk of crops on his estate were likely to fail for lack of rain. However, Oblomov planned to improve his property, making grave schemes to affect his plough-land and its taxation, to take stricter step against laziness and vagrancy on the part of the peasantry and to order his own life in the country. His friend Andrey Schtoltz also advised him as follows:

"Go to Oblomovka, and there learn what sowing and grinding mean, and why the peasant is poor or rich. Walk the fields, attend the local elections, visit the mills, and linger by the river wharves" (Goncharov, Ivan, 1915, p. 161). Therefore, Oblomov engrossed to figure out a new house containing every kind of facilities of life. As he retrieves his beloved Olga, "Yes. I want to live upon my estate and am making a few preparations for doing so" (Goncharov, Ivan, 1915, p. 167).

Consequently, Oblomov could do nothing in this regard because of his inertia, procrastination and indecision. As we read in the novel:

"Such is the philosophy which our Plato of Oblomovka, elaborated for the purpose of lulling himself to sleep amid the problems and the stern demands of duty and of destiny. He had been bred and nourished to play the part, not of a gladiator in the arena but of a peaceful onlooker at the struggle. Never could his diffident, lethargic spirit have faced either the raptures or the blows of life. Hence, he expressed only one of its aspects, and no mind, either to succeed in it, or to change anything in it, or to repent of his decision. As the years flowed on both emotion and repining came to manifest themselves at rarer and rarer intervals, until, by quite, imperceptible degrees, he became finally interned in the plain, otiose tomb of retirement, which he had fashioned with his own hands, even as desert anchorites who have turned from the world dig for themselves as material sepulchre. Of reorganizing his estate, and removing thither with his household, he had given up all thought" (Goncharov, Ivan, 1915, pp. 279-280). Therefore, Oblomov is inert and irresolute dreamy person like Hamlet though plunged in a slough of apathy, from which nothing can arouse him.

However, Ivan Goncharov's novel "Oblomov" appeared in 1859 , just only two years earlier the liberation of the serfs in 1861, during the great public debate preceding the emancipation of the serf. The emancipation of the serfs supplied a new class of the proletarians to the Russian industry, which made the development of capitalism possible. Nevertheless, the power of capital was still seriously restrained by the interests of the landed and serf-owning feudal nobility and the absolute Tsarist State. Therefore, the economic conditions in the patriarchal countryside of the feudal Tsarist Russia prevented the development of home market. Most of the large industrial enterprises depended upon receiving State orders especially for the railways and Army. Nevertheless, a new class of bourgoisified nobility and industrialist bourgeoisie began to emerge and a few members of this class became the pioneer of modern ideas in Russia. The capitalists and tax collectors began to shake the old foundations of the patriarchal countryside and peasant life. As a result, the old foundations of peasant economy were rapidly broken up for scrape.

The private cause of Oblomov's lethargy and the evasion of adult responsibility is arguably at the source of his Oblomovism and presumption of superiority to 'them', meaning those who have to dress themselves or occasionally move house (this crisis faces Oblomov at the novel's opening), no doubt the fondest of Oblomov's private illusions. In the end even, his lethargy is idealised into the demonstration of what he considered an ideally tranquil aspect of human existence. His Oblomovism is not an excuse for inactivity, indecision, procrastination and inertia so much 
as a deliberate rejection of all normal human activity as fatuous and irrelevant, and his superiority to 'them' is indeed the superiority of his 'crystal, pellucid soul', as Schtoltz describes it, to the showy falsehood and oceans of evil which surge round him in his life. Schtoltz identifies this change, announcing welcome to new order of capitalism and farewell to the landed and serf-owning old Oblomovka of feudalism as follows:

"It would be useless now to tell you that your Oblomovka is no longer in ruins, that its turn is come again, and that it is basking in the rays of the sun. It would be useless now to tell you that, some four years hence, it will have a railwaystation, and that rubbish there, and that before long an iron road will be carrying your grain to the wharves, and that already local schools have been built. Such a dawn of good fortune would merely affright you; it would merely cause your unaccustomed eyes to smart. Yet along the road, which you could not tread, I will lead your little Andrei; and with him, I will put into practice those theories whereof you and I used to dream in the days of our youth. Farewell, Oblomovka of the past! You have outlived your day!" (Goncharov, Ivan, 1915, pp. 298-299).

In this manner, Ivan Goncharov depicted this new capitalist development realistically, which is much more than the lovingly detailed narration of Ivan Goncharov's descriptive manner, though this aspect of the work is outstanding even in a literature so rich in examples of detailed realistic word-painting as is nineteenth century Russian literature. The intimacy of the descriptions devoted to Oblomov's St Petersburg apartment, the complexity of the imagery describing his mental processes, the fond, clockridden, soporific abundance of lyrical narrative that tells Oblomov's last years are high points only in a work that has a marvellously substantial feel about its realistic manner in all its parts. Its realism embraces, in a more intimate and explorative sense than any hitherto, the real character of the mutual interdependence existing between master and serf in the mid nineteenth-century feudal Tsarist Russia. Ivan Goncharov provides the profounder awareness of the real socio-economic forces of capitalism that were threatening to engulf the nobility isolated and cocooned in their respective patriarchal feudal Oblomovkas, their respective patriarchal country estates. The tension between the new and the old social values in the feudal Tsarist Russian social formation, although seemingly offered in excessively black-and-white terms if Oblomov were compared with the positive hero, Schtoltz, are suggested more subtly by the conflict between Oblomov's embodiment of a decayed idealism and guileful realism of the money-grubbing capitalist world surrounding him. If in the end Ivan Goncharov seems over-indulgent towards his hero by allowing him a kind of metaphysical redemption, the realism of his work, by its very scale and profundity invites us to sympathize just as much as to censure, to understand and therefore to forgive, though without proselytizing, simply by offering us a likeness. If we do not recognize the reality of Oblomov, we simultaneously do not recognize the Oblomov in the land-owning and serf- owning feudal class or in each of us.

In fact, the figure of Oblomov acquired great stature, prominence and importance, which was acknowledgement of the extent to which literature in the post-Crimean-War period in Russia had begun to exert an authority that tended to usurp the authority of Russian Orthodox Church and Tsarist state. Alexander Turgenev contributed to this process as much as any literary figure of the period, but the importance of literature as a moral and educative influence was appreciated more fully by the younger generation of the intelligentsia. We find in Oblomov the conflict of new and old social values of the feudal Tsarist Russian social formation. Oblomov adores the old values and traditions of the past and abhors the new ones. He lives in the past dreaming for his past and childhood. He prays that the next day will be the same, as the previous (Gerschenkron, 1975, p.699; Borowec, 1994, p. 562).He is an old fashioned, Eastern, and Asiatic person rather than modern and Western one in his manners and life style. Richard Peace opines, "Oblomov-who was raised with a pseudo-German education, who wears a Germanic (yet "Eastern") shlafrok gown, and who lives in the Westernized imperial capital Petersburg (Peace, Richard., 1991, p. 13) — is a symbol of the East. Oblomov always wears khalat, the Persian dressing-gown, which is the proof of his Easternness (Diment, G., 2001, p. 100). Ivan Goncharov tells us about the dressing-gown of Oblomov as follows:

"The costume in question consisted of a dressing-gown of some Persian material-a real Eastern dressing-gown-a garment that was devoid both of tassels and velvet facing and waist; yet so roomy that Oblomov might have wrapped himself in it once or twice over. Also, in accordance with the immutable custom of Asia, its sleeves widened steadily from knuckles to shoulders. True, it was a dressing-gown which had lost its pristine freshness, and had, in places, exchanged its natural, original sheen for one acquired by hard wear; yet it retained both the clarity of its Oriental colouring and the soundness of its texture" (Goncharov, Ivan, 1915, p. 10).

Ivan Goncharov draws the portraiture of Oblomov as his eyes are cast as "dark-gray, but with the absence of any kind of definite ideas that do occur to him wander "across his face like a free bird" (Goncharov, Ivan, 1915, p. 7). Oblomov's features, dress, mannerisms, his small puffy hands, his soft shoulders, one would conclude that he possessed an effeminate body" (Goncharov, Ivan. 1915, p. 8). Moreover, even his "whole soul" describes his behaviour towards life. In fact, indecision, procrastination and sluggishness are characteristics of an exploiting feudal class. Oblomov becomes addicted to his bed from where he is dreaming of a different life, making big plans and scheme, but unable to put them into practice because of indecision, procrastination and sluggishness.

This absence of any kind of definite ideas encompasses Oblomov's inactivity and indecision, spirituality, purity, and incompetence in practical affairs. He does not end up with the heroine Olga, but rather with his landlady. This provides a counterpoint to the immaculate softness described in 
Oblomov's features, dress, mannerisms, his small hands, and even his "whole soul". Indeed, if one takes Oblomov's robe as "an essential part of Oblomov's attitude towards life" (Peace, 1991, p. 72), Oblomov's Oriental backwardness would be apparent. Oblomov's non-Western shlafrok or khalat is in fact a symbol of paradox of nineteenth-century, which demonstrates how Russian social formation of the nineteenth century is articulated simultaneously as antiWestern, it also reinforces that the character of Oblomov demonstrates certain aspects of philistine, reflecting "Russian provincial stagnation" (Ehre, 1973, p. 178). Frank summarizes the received formulation as follows:

"Some critics have interpreted it as a reference to an 'Asiatic' tendency in the Russian character; and Oblomov's efficient and successful friend Schtoltz, whose father is German, certainly forms a 'Western' contrast to Oblomov's indolence and practical helplessness" (Frank, 2007 ). This is not to say that Oblomov is unique among the nineteenthcentury Russian literary characters for his display of Easternness of Russia. Rather, he and Andrey bear contradictory and paradoxical symbolic currency that was inherent to the cultural milieu. Instead of emerging as diametric opposites, as Ehre has argued (Ehre, 1973, p.196), a close reading of the stereotypes in the novel demonstrates that both characters exist on a continuum between images of Easternness (Russianness) and Westerness. Oblomov has become a symbol of indolence and inactivity, being a completely lethargic person. He spends his time mostly in bed or trying to get up. He declares to his servant his worry about the worsening condition of his estates, but does nothing about it. The family and estate's name itself tell the reader about the condition that the residence was in-the Russian word Oblomov means a broken-offs piece.

Therefore, Oblomov and Hamlet represent the situation of transition period from feudalism to capitalism. For this reason, they could not fit into the new situation and trapped in inactivity, procrastination and indecision. Oblomov was a person in constant apathetic lethargy. He was tormented by uncertainty, procrastination and undecidability on the question what he was to do? Hamlet is also indolent and indecisive person and remained in between the question: to be or not be? In this way, Oblomovism and Hamletism of the both characters lead them in the confusion of betweenness of to be or not be and what is to be done? For this reason, the Russian writers and political leaders concentrated on the questions what is to be done or to be or not be? Bazarov in Ivan Turgenev's novel "Fathers and Sons" gave an Oblomovlike or Hamlet-like answer to the question, suggesting fate naturally. The leisure, procrastination, indolence, indecision and laziness transformed human being into an animal. Nevertheless, on the contrary, labour and work transform the great apes and monkeys into Homo sapiens. Labour not only makes the hands able to work but also makes the development of the economic productive system. "Hands are not only organs of labour but a product of labour" (Quoted in Marx and Engels, 1976, p. 453).

In 1862, four years after Ivan Goncharov's novel
"Oblomov" a novel by Nikolai Chernyshevsky appeared entitled "What is to be Done? In this novel, he answered the question to produce new men and women. In this manner, he introduced new people such as Vera Pavlovna, Lopukov, Kirsanov and above all proto revolutionary hero Rekhmetov. They were new people or the raznochintsy, who wanted a peasant revolution in the feudal Tsarist Russia. Similarly, Dobrolyubov wrote an essay entitled "What is Oblomovism? It is not only masterly critical evaluation of the novel, but also a remarkable publicist document, which used the novel "Oblomov", as a means of denouncing Oblomovism of the older generation of the gentry intelligentsia and the consequent need for their replacement, as an influential force in the coercive feudal Tsarist Russian social formation, by younger generation with radical ideas. No doubt, Dobrolyubov also sought a peasant revolution in the feudal Tsarist Russia.

The impulse for change in the coercive feudal Tsarist Russian social formation, presented among sections of the landed and serf-owning nobility since the beginning of the nineteenth century, the defeated Decembrist movement of 1825 was also an expression of this impulse. This impulse held less appeal for them as soon as it began to acquire the revolutionary characteristics, which led Nikolai Chernyshevsky, Belinsky and Nikolai Dobrolyubov, as spokespersons of the raznochintsy, to proclaim, no matter how circumspectly for fear of the censorship, the cause of peasant revolution and the role of the raznochintsy as its leaders. Nikolai Dobrolyubov's review of Oblomov "What is Oblomovism?" became one of the shots fired in an incipient internecine warfare between the 'fathers' and 'sons', between the older liberal-inclined intelligentsia, who came almost entirely from the landed and serf-owning nobility, and the younger radical intelligentsia, the raznochintsy drawn from among the less privileged elements of the feudal Tsarist Russian social formation.

In 1902, Vladimir Lenin wrote an eminently political treatise entitled "What is to be Done? His answer to the question was Socialist revolution. Socialist revolution used to activate the masses of proletarians and peasants and decapitate Oblomoves of the landed and serf-owning nobility. Oblomov is the portrait of the hero epitomized the indolence, stagnation and indecision of the landed and serfowning nobility. He was coddled in his ST Petersburg apartment by ineptly devoted serf Zakhar and the selfillusion of his patrician idleness, sloth, procrastination and indecision. However, Oblomov is in fact, a masterly study of a syndrome, "the all-prevalent malady of Oblomovka" (Goncharov, Ivan, 1915, p.101), "the Disease of Oblomovka" (Goncharov, Ivan, 1915, p.231), and the apathetic malady, of Oblomovka, (Goncharov, Ivan, 1915, p.248), symptoms of which felt by Ivan Goncharov, diagnosed by Nikolai Dobrolyubov as Oblomovism, and prescribed and injected by Nikolai Chernyshevsky by his utopian socialist injection of anti-Oblomovism but all in vain.

At last, Vladimir Lenin operated the Russian social formation to remove this syndrome from it by Bolshevik 
Revolution. In this regards, for Vladimir Lenin Oblomov was an anti-revolutionist person and Oblomovism was an antirevolutionary tendency, syndrome and a remnant of feudalism. The germs of Oblomovism remained as remnants of feudalism in new Socialist social formation of Russia. For this reason, Vladimir Lenin condemned Oblomov and Oblomovism repeatedly in his writings and speeches, comparing his contemporary Menshevik leaders with Oblomov because of inertia, procrastination and irresolution. Oblomov and Oblomovism both in Vladimir Lenin's opinion are product of feudalism and would be out of place in the Socialist formation. Vladimir Lenin used it on many occasions seemed to find Oblomov syndrome still prevalent in Soviet Russia. " The old Oblomov," he wrote, " has remained, and for a long while yet he will have to be washed, cleaned, shaken and thrashed if something is to come of him" (Lenin, V. I., 1970, p.223).

\section{Conclusion}

The researcher tries to compare the two literary characters Hamlet and Oblomov because of their indecision, indolence and procrastination from Marxist point of view. The researcher also attempt to examine the main features of the characters of Hamlet and Oblomov and then to draw a parallel between them. At the end of this analytical and comparative study of them, the noticeable point is that these two literary characters share astonishing similarities with each other that they seem the same or two faces of one coin. In fact, Hamlet is Oblomov of his age and Oblomov is Hamlet of his age. Although they come from two different periods; however, considering the core of psychological and social points, they are close to each other. It can be concluded from this comparison that these two literary characters come from the landed and serf-owning feudal nobility; therefore, they are indecisive and sluggish. This comparison is nothing but the study of class nature of the land-owning and serf-owning feudal nobility. The indecision, procrastination and sluggishness of the both characters of the landed and serf-owning feudal nobility are based upon the private property, which breeds and nourishes this type of negative and flawed characters that will completely disappear with elimination of private property in future social formation of Communism. Still there are many other areas of the study left untapped and unexplored. The research suggests comparison of the both literary types: Oblomov and Hamlet with the other superfluous heroes of world literature. The study also suggests investigating Vladimir Lenin's views on the character of Oblomov. Therefore, the present study may prove useful and helpful to suggest clues to the unexplored and untapped areas on the subject for future research scholars.

\section{References}

[1] Alexander, Peter. (1953). Hamlet Father and Son: The Lord Northcliffe Lectures University College. London, Oxford: Clarendon.
[2] Althusser, Louis. (1969). For Marx. Paris, France: The Penguin Press.

[3] Althusser, Louis. (1971). Lenin and Philosophy and Other Essays. Trans. Ben Brewster. London, Great Britain: New Left Books.

[4] Belsey, Catherine. (1980). Critical Practice. London, Great Britain: Routledge.

[5] Belsey, Catherine. (1985). the Subject of Tragedy: Identity and Difference in Renaissance Drama, London: Methuen.

[6] Borowec, C. (1994). "Time after Time: The Temporal Ideology of Oblomov," The Slavic and East European Journal, 38. 4, pp. 561-573.

[7] Caudwell, Christopher. (1977). Illusion and Reality. London: Lawrence \& Wishart.

[8] Cornwell, Neil. (2001).The Routledge Companion to Russian Literature. London: Routledge. pp. 111-122.

[9] Diment, Galya. (1998). "The Precocious Talent of Ivan Goncharov," In: Galya. Diment (ed.), Goncharov's Oblomov: A Critical Companion, pp. 3-50. Evanston, Illinois: Northwestern University Press.

[10] Diment, Galya. (2001). "Ivan Aleksandrovich Goncharov," In J. Ogden and J. Kalb (eds.), Russian Novelists in the Age of Tolstoy and Dostoevsky. Detroit, pp. 90-106.

[11] Dobrolyubov, Nikolai Aleksandrovich. (1956). "What is Oblomovism?" In: Selected Philosophical Essays. Moscow. Pp. 182-194, 204-217.

[12] Eagleton, Terry. (1986). William Shakespeare. Oxford: Basil Blackwell.

[13] Ehre, M. (1973). Oblomov and His Creator. Princeton.

[14] Ehre, M. (1985). "Goncharov, Ivan Aleksandrovich," in: V. Terras (ed.), the Handbook of Russian Literature. New Haven, pp. 178-179.

[15] Egan, Gabriel. (2004). Shakespeare and Marx. Oxford: Oxford University Press.

[16] Frank. J. (2014). "Being and Laziness," The New Republic, TheNewRepublicMag.(web),http://www.mewrepublic.com/art iclebeing-and laziness,29.1.2007,25.1.2014 (acc.)

[17] Gerschenkron, A. (1975). "Time Horizon in Russian Literature," The Slavic Review, 34. 4, pp. 692-715.

[18] Goncharov, Ivan. (1915). Oblomov. New York: The Macmillan Company.

[19] Jameson, Fredric, (1995). Marx's Purloined Letter. New Left Review. 1/209, January-February 1995.

[20] Kuhn, A. (1971). "Dobrolyubov's Critique of Oblomov: Polemics and Psychology.” Slavic Review 30.1, 1971, pp. 93-109.

[21] Leerssen, J. (2007). "Imagology: History and Method," "Image," "Identity/ Alterity/Hybridity," in: M. Beller, J. Leerssen (eds.), Imagology: The Cultural Construction and Literary Representation of National Characters, Amsterdam, pp. 17-32, and 335-344.

[22] Lenin, V. I. (1970). Collected Works, Vol. 33. Moscow: Progress Publishers. 
[23] Lifshitz, Mikhail. " (1938). Literature and Marxism: A Controversy. New York: Critics Group.

[24] Lukacs, Georg. (1981), the Historical Novel. Penguin Books.

[25] Lunacharsky, Anatoly. (1973). "Bacon and the characters of Shakespeare's Plays" in Lunacharsky on Literature and Art, pp. 218-243.Moscow: Progress Publishers.

[26] Marx, Karl and F. Engels. (1965) Selected Correspondence. Moscow: Progress Publishers.

[27] Marx, Karl and F. Engels. (1975). Marx-Engels Reader. Robert C. Tucker. Ed. 2nd edn. New York: Norton.

[28] Marx, Karl and F. Engels. (1975). "The Manifesto of the Communist Party". The Marx-Engels Reader. Robert C. Tucker. Ed. 2nd edn. New York: Norton. Pp. 469-500.

[29] Marx, Karl and F. Engels. (1975). Collected Works, Vol. 25. New York: International Publishers.

[30] McLean, H. (1998). "The Countryside," in: M. Jones, R. Miller (eds.), the Cambridge Companion to the Classic Russian Novel, Cambridge, pp. 41-62.

[31] Muza, A. (2000). "Science, Philosophy, Muse: Chekhov's Three Germans," in: Gold Fusion, pp. 185-196.

[32] Peace, Richard. (1991). Oblomov: A Critical Examination of Goncharov's Novel. United Kingdom: Birmingham Slavonic Monographs of Department of Russian Language and Literature, University of Birmingham.

[33] Rafi, Abu Saleh Md. (2012). The Comparative Nature in Comparative Literature: A Case Study of Some Major Bengali Literary Works in Conjunction of Other National Literatures in: Bangladesh Research Foundation Journal. Vol 1, ISSN: 2224-8404, (February 2012). pp. 1-14.

[34] Reeve, Franklin. "Oblomovism Revisited," American Slavic and East European Review, XV, pp. 112-118.
[35] Seeley, F. (2003). "Oblomov," The Slavonic and East European Review, 54. 3, 1976, pp. 335-354.

[36] Seeley, F. "The Heyday of the 'Superfluous Man' in Russia," The Slavonic and East European Review, XXXI, pp.92-112

[37] Senese, D. (2003). Nikolai Aleksandrovich Dobrolyubov, In: A Gillespie (ed.), Russian Literature in the Age of Realism (= Dictionary of Literary Biography, 277), Gale, Detroit, pp. 8093.

[38] Setchkarev, V. (1967). "Andrey Schtoltz in Goncharov's Oblomov: An Attempted Reinterpretation," in: To Honour Roman Jakobson. Essays on Occasion of His Seventieth Birthday, 3, The Hague, Paris 1967, pp. 1799-1805.

[39] Shakespeare, William. (2005). Hamlet. London: Penguin.

[40] Shishkin, M. (2008). "Afterword," in: I. Goncharov, M. Schwartz (trans.), Oblomov, New York, pp. 545-552.

[41] Smirnov, A.A. (1936). Shakespeare: A Marxist Interpretation, New York: Critics Group.

[42] Stacy, R. H. (1985). "Dobrolyubov, Nikolai Aleksandrovich." The Handbook of Russian Literature, (ed.), Victor Terras. New Haven: Yale University Press. p. 101.

[43] Stallman, Leon. "Oblomovka Revisited," American Slavic and East European Review, VII, pp. 45-77.

[44] Turgenev, Ivan. (1990). Sketches from a Hunter's Album, trans. Richard Freeborn. London: Penguin.

[45] Walker, Joshua S. (2013). "Neither Burgher nor Barin: An Imagological and Intercultural Reading of Andrey Schtoltz in Ivan Goncharove's Oblomov (1859)", in: Slevene, International Journal of Slavic Studies, Vol. 2, No. 2. pp. 5-30.

[46] Wiggins, Kathleen Cameron. (2001). the Drama in Disguise: Dramatic Modes of Narration and Textual Structure in MidNineteen-Century Russian Novel. A Ph. D Dissertation. University of California, Berkeley. 